\title{
PENDIDIKAN SENI BUDAYA DAN PRAKARYA (SBdP) SEBAGAI STRATEGI INTERVENSI UMUM BAGI ANAK BERKEBUTUHAN KHUSUS
}

\author{
Lia Mareza \\ e-mail: liamareza@yahoo.com \\ PGSD-FKIP Universitas Muhammadiyah Purwokerto
}

\section{ABSTRACT \\ Cultural Art And Craft Education As A General Intervention Strategy For Special Needs Children}

\begin{abstract}
Art education can shape an individual's mental character, socio cultural personality, creativity and intellectual. Cultural art education is not only as a means of developing the knowledge and skills but as a general intervention strategies for children with special needs that based on socio-cultural. cultural arts and craft education has a uniqueness, significance and usefulness through activities to create, to appreciate and to express, so that children have role in the development of cognitive, affective and psychomotor than as aspects of catharsis in channeling the emotions as well as to stimulate active participation and improve the independence and directions on special needs childreen. The purpose of the use of intervention strategies was to help teachers knowing that the characteristic was associated with the competence of the child. This study was a qualitative research conducted in SD Negeri 1 Tanjung Purwokerto as one Inclussive School. Subject of research was principal, classroom teachers, assistant teachers, students and parents. The result of the research was intervention strategy can improve the ability of children. This was due to the orientation of making art more oriented to the modification process, the content of a work and the product.
\end{abstract}

Keywords: Art Education, Intervention Strategies, Children with Special Needs

\section{PENDAHULUAN}

Kekayaan seni budaya di Indonesia sangat beragam dan memiliki nilai sejarah yang sangat tinggi. Beragam motif, karya seni rupa, seni tari bahkan hingga seni musik harus tetap lestari dan berkembang sebagai wujud identitas bangsa. Pendidikan seni budaya dan prakarya diberikan pada siswa sekolah dasar agar tetap menumbuhkan rasa kecintaan siswa terhadap seni budaya Indonesia. Rasa kecintaan ini dapat menimbulkan minat, kreativitas, dan apresiasi anak terhadap seni dan budaya bangsa. PP No. 19 tahun 2005 tentang Standar Nasional Pendidikan menyebutkan bahwa pendidikan seni budaya meliputi berbagai aspek kehidupan. Kompetensi dasar muatan lokal yang berkenaan dengan seni, budaya, dan keterampilan diintegrasikan ke dalam mata pelajaran Seni Budaya dan Prakarya (SBdP). Pendidikan seni budaya memposisikan siswa sebagai pewaris budaya bangsa yang kreatif sekaligus memiliki kecerdasan intelektual.

Pendidikan seni sebagai wadah bagi siswa untuk menuai segala pengetahuan sehingga mampu menjadikan siswa yang memiliki kecerdasan intelektual yang kreatif. Perlunya rencana pendidikan yang tersusun secara terstruktur agar dapat membantu guru dan orang tua dalam menerima kurikulum dan peraturan sekolah demi kemampuan akademis dan potensi siswa. Strategi pembelajaran yang digunakan untuk anak berkebutuhan khusus jelas berbeda dengan anak normal. Anak berkebutuhan khusus yaitu anak yang memerlukan penanganan khusus karena adanya gangguan perkembangan dan kelainan yang dialami oleh anak. Heward (2003) menjelaskan bahwa anak berkebutuhan khusus yaitu 
Pendidikan Seni Budaya dan Prakarya (SBdP) sebagai Strategi Intervensi Umum bagi Anak Berkebutuhan Khusus (Lia Mareza)

anak dengan karakteristik khusus yang berbeda dengan anak pada umumnya baik secara mental, emosi atau fisik. Anak berkebutuhan khusus adalah anak yang secara pendidikan memerlukan strategi yang spesifik yang berbeda dengan anak-anak pada ummnya. Tanpa strategi intervensi yang tepat, anak berkebutuhan khusus seringkali kehilangan fokus dalam proses pembelajaran di sekolah. Intervensi yang ditujukan kepada anak berkebutuhan khusus merupakan hal yang dibutuhkan oleh anak. Anak diberikan kebebasan dalam bereksplorasi, menjadi ingin tahu, dan belajar hal-hal baru ketika anak memang menginginkannya, dan hal tersebut tidak terjadwalkan oleh waktu seperti yang telah dijelaskan dalam kurikulum. Anak diberikan kesempatan untuk mencoba membuat menciptakan sebuah karya seni, membuat sesuai dengan kreasi anak, sehingga mampu memenuhi kebutuhan emosional anak. Proses penciptaan karya seni tentunya dilakukan dalam keadaan rileks, dorongan batin, pengungkapan fikiran, perasaan bahkan naluri yang terdalam, hal ini disebabkan karena eksplorasi penciptaan karya seni berkaitan dengan perasaan artistik dan estetika sehingga karya yang dimunculkan tiap individu pasti akan berbeda.

Pembelajaran seni di tingkat pendidikan dasar bertujuan untuk mengembangkan kesadaran seni dan keindahan dalam arti umum, baik dalam domain konsepsi, apresiasi, kreasi, penyajian, maupun tujuan-tujuan psikologis-edukatif untuk pengembangan kepribadian siswa secara positif, sehingga individu lebih memahami budaya sebagai salah satu tujuan dari pendidikan (Permen No. 57 Tahun 2014). Tujuan pembelajaran seni dapat tercapai jika guru memiliki kompetensi dan persepsi yang baik dalam pelaksanaan pembelajaran seni. Pendidikan seni dan budaya dapat dijadikan sebagai media alternatif dalam masa pendampingan melalui aktivitas kreatif anak berkebutuhan khusus yang bertujuan selain menghasilkan sebuah karya seni yang estetis juga sebagai sarana katarsis atau proyeksi anak berkebutuhan khusus dalam keinginan untuk mencoba mengungkap perasaan terdalamnya yang selama ini sulit diungkapkan.

Tujuan dari penggunaan strategi intervensi yang tepat dapat membantu guru dalam mengetahui karakteristik dikaitkan dengan kompetensi siswa. Guru dapat mengetahui kemampuan serta kelemahan setiap siswa dalam perkembangan kognitif dan psikomotornya melalui pengamatan pada saat proses pembuatan karya seni. Intervensi yang diberikan guru diharapkan mampu menggali kemampuan siswa dalam proses pembuatan karya seni atau karya ketrampilan.

\section{METODE}

Penelitian ini merupakan penelitian kualitatif yang dilaksanakan di SD Negeri 1 Tanjung Purwokerto sebagai salah satu sekolah inklusi. Subjek penelitian yaitu kepala sekolah, guru kelas, guru pendamping, siswa dan wali murid. Pengumpulan data dalam penelitian kualitatif dapat dilakukan dengan beberapa macam teknik pengumpulan data. Penelitian ini menggunakan tiga teknik pengumpulan data. Teknik pengumpulan data yang digunakan yaitu metode wawancara, metode observasi, dan metode studi dokumen.

\section{HASIL DAN PEMBAHASAN}

Seni lahir dilatarbelakangi adanya dorongan bermain-main (play impuls) yang dalam diri si pembuatnya. Segala sesuatu yang dilakukan oleh orang bukan atas dorongan kebutuhan pokoknya, melainkan karena kehendak akan kenikmatan ataupun karena dorongan psikologis (Mikke, 2011). The Liang Gie (1976: 61) menyebutkan seni merupakan suatu kegiatan manusia yang menjelajahi dan menciptakan realita baru dalam suatu cara yang di luar akal dan berdasarkan penglihatan serta menyajikan realita itu secara perlambang atau kiasan sebagai sebuah kebulatan dunia kecil yang mencerminkan sebuah kebulatan dunia besar. Kuswarsantyo (2009: 3) seni adalah ekspresi jiwa 
manusia yang tertuang dalam berbagai bentuk karya seni. Tari dengan ekspresi gerak, musik dengan suara dan vokal, teater dengan ungkapan ekspresi dan vokal, rupa dengan berbagai media, aliran dan gaya, merupakan ungkapan ekspresi yang di dalamnya sarat dengan simbol.

Pendidikan seni budaya bagi anak berkebutuhan khusus bukan hanya sebagai pemberian informasi dan pembentukan ketrampilan saja, namun lebih kepada usaha untuk mewujudkan keinginan, kebutuhan dan kemampuan individu sehingga tercapai pola hidup yang lebih berkualitas dan juga sebagai persiapan di kehidupan yang akan dating pada saat dewasa kelak. Strategi intervensi bagi anak berkebutuhan khusus melalui pendidikan seni budaya, perlu dilakukan agar orang tua dan guru mengenal perbedaan individual yang mencakup perbedaan fisik dan psikologis dalam ranah kognitif, afektif, dan psikomotor. Penelitian yang dilakukan Holmberg (2014:2) memnemukan bahwa perencanaan kurikulum didefinisikan untuk tujuan sebagai perencanaan guru pendidikan berdasarkan kurikulum nasional, dengan tujuan untuk mendukung siswa mengambil bagian dalam sebuah komunitas sosial, akademik dan budaya untuk perbedaan dalam kemampuan dan bakat yang dimiliki pada tiap anak berkebutuhan khusus sesuai dengan kemampuan dan kapasitas anak ditinjau dari segi fisik dan intelegensi serta kreativitasnya.

Mata pelajaran yang disesuaikan dengan minat dan pilihan anak sehingga anak dapat berkembang potensinya sebaik-baiknya. Sehingga waktu penyelesaian suatu tingkat kemahiran tidak akan sama, antara anak satu dengan yang lain. Hal ini dikarenakan dalam proses penciptaan sebuah karya seni yang mengolah emosi dan pikiran yang telah mengendap. Semua emosi dan pikiran akan tersalurkan sehingga membantu dalam proses katarsis dari anak dalam penyampaiannya secara simbolik yang diutarakan dalam wujud karya seni.

Proses yang dilakukan dalam berkarya seni juga berfungsi sebagai pola dalam mengolah aspek kognitif, afektif dan psikomotorik anak, yaitu melatih koordinasi pikiran, perasaan dan aktivitas fisik secara bersamaan. Selain sebagai media dalam pengungkapan emosi, dalam proses pembuatan karya seni dapat dimasukkan pendampingan yang bermuatan terapi seperti mengarahkan aktivitas pembuatan karya seni dengan memori anak akan objek atau symbol yang digunakan pada sebuah karya. Guru dan orang tua perlu mempertimbangkan kelayakan tugas sebagai kegiatan individu atau kegiatan kelompok. Hal ini dikarenakan tidak setiap siswa mampu mengerjakannya dalam jenjang waktu yang sama. Sebaliknya untuk tugas yang cukup kompleks cocok untuk kegiatan kelompok. Hal ini dapat mengajarkan kepada siswa untuk bersosialisasi dengan teman sebayanya. Intervensi seperti ini yang merupakan kegiatan inti agar anak dapat langsung menceritakan maupun menyampaikan secara tidak langsung makna atau pesan yang ingin disampaikan. Anak akan menjadi semakin rileks dalam proses pembuatan karya seni, karena pada dasarnya pendidikan seni dan budaya dapat dijadikan sebagai wadah bagi anak berkebutuhan khusus dalam menggali potensi diri, melatih konsentrasi hingga menjadikan anak dapat bersosialisasi seperti pada anak normal umumnya. Belajar melalui seni artinya, anak akan mengembangkan pengetahuannya, mempelajari dan mengekspresikan pemahamannya menjadi seni melalui bentuk-bentuk karya seni, sehingga siswa dapat berpikir imajinatif dan kreatif dalam mengkontruksi makna.

Belajar tentang seni artinya, dapat mengembangkan kecerdasan akan pengetahuannya tentang seni itu sendiri. Retnowati dan Prihadi (2010: 12) mengemukakan bahwa kecerdasan tersebut merupakan landasan bagi seni rupa, seni musik, seni tari, dan prakarya. Melalui seni, siswa tidak hanya menemukan cara untuk berkomunikasi dan ekspresi diri, tetapi juga alat untuk mengkonstruksi makna dan belajar hampir setiap mata pelajaran secara efektif. Hal ini sangat nyata jika seni tidak hanya diajarkan sebagai mata pelajaran tetapi juga diintegrasikan kedalam seluruh kurikulum pada setiap jenjang pendidikan. Intervensi dalam mengaplikasikan substansi dari kurikulum tidak hanya menekankan para siswa agar mudah memahami mata pelajaran yang diajarkan. Akan tetapi juga bertujuan agar seluruh siswa termasuk anak berkebutuhan khusus, dapat saling memahami, menghormati, dan menghargai satu sama lain. Sehingga guru di sekolah dan orang tua sepakat 
Pendidikan Seni Budaya dan Prakarya (SBdP) sebagai Strategi Intervensi Umum bagi Anak Berkebutuhan Khusus (Lia Mareza)

untuk mengajarkan secara bersama-sama mengenai cara bersikap dan cara menghadapi siswa difabel dan siswa yang normal di sekolah secara santun dan manusiawi. (Prastiyono dalam Agung Nugroho, 2016). Pendidikan inklusif memberikan berbagai kegiatan dan pengalaman, sehingga semua siswa dapat berpartisipasi dan berhasil dalam kelas. Apresiasi dan kreasi seni merupakan bentuk ekspresi seni yang dituangkan dalam bentuk karya.

Terdapat banyak perbedaan antara potensi atau bakat termasuk kemampuan seperti intelektual, akademis, kreativitas, sosial, dan seni. Demikian pula banyak terdapat talenta yang dimiliki anak berkebutuhan khusus, adalah penting untuk mengumpulkan informasi baik dari segi potensi maupun performa yang dapat diamati sehingga semua infomasi ini akan membantu mengenali bidang potensi spesifik yang dikuasai anak yang dibutuhkan demi perkembangan pendidikannya.

\section{SIMPULAN}

Intervensi yang dilakukan selama ini seringkali memiliki keterbatasan dalam batasan dan pola sehingga materi yang diberatkan hanya pada materi pokok saja dan mengenyampingkan materi pendidikan seni yang merupakan startegi intervensi belajar yang menyenangkan bagi anak berkebutuhan khusus. Kurikulum berisi mengenai materi yang akan diajarkan sedangkan strategi intervensi mengarah kepada cara kurikulum ini disampaikan atau diajarkan yang dapat dilakukan melalui modifikasi proses pembelajaran secara akademis dan apresiasi karya seni. Pembelajaran seni budaya dan prakarya bagi anak berkebutuhan khusus harus dapat memanfaatkan lingkungan sebagai kegiatan apresiasi dan kreasi seni. Pendidikan seni budaya tidak hanya berfungsi sebagai pengembangan pengetahuan dan keterampilan, melainkan menjadi sarana dalam pengembangan karakter pribadi yang berlandaskan sosial budaya. Kegiatan berekpresi, berkreasi, dan berapresiasi memiliki makna dalam kehidupan sehari-hari tidak hanya dalam bentuk pengetahuan (konsepsi) dan keterampilan (ekspresi), melainkan memiliki makna yang dalam berupa sikap (apresiasi).

\section{DAFTAR PUSTAKA}

Heward. 2003. Exceptional Children an Introduction to Special Education. New Jersey: Merill, Pretince Hall.

Holmberg,dkk. 2014. Inclusive And Individually Adapted Education In Norway Results From A Survey Study In Two Municipalities Focusing The Roles Of Headteachers, Teachers And Curriculum Planning. International Journal Of Special Education, 29 (1): 47 - 60.

Kuswarsantyo. 2009. Materi Dasar Apresiasi Seni. Yogyakarta : UNY

Liang, Gie. 1976. Garis Besar Estetika. Yogyakarta: Karya

Mikke, S. 2011. Diksi Rupa. Yogyakarta: DictiArt Lab

Peraturan Menteri Pendidikan dan Kebudayaan Republik Indonesia Nomor 27tahun 2014 tentang Kurikulum 2013 Sekolah Dasar/ Madrasah Ibtidaiyah.Peraturan Pemerintah Republik Indonesia Nomor 19 tahun 2005 tentang Standar Nasional Pendidikan.

Retnowati, Tri Hartiti, dkk. 2010. Pembelajaran Seni Rupa. Yogyakarta: Badan Penerbit Universitas Negeri Yogyakarta. 